\title{
Reinfection of Liver Graft by Hepatitis C Virus after Liver Transplantation
}

\author{
C. Féray, ${ }^{\star *}$ D. Samuel, ${ }^{\star}$ V. Thiers, ${ }^{\star}$ M. Gigou, ${ }^{\star}$ F. Pichon," A. Bismuth, \\ M. Reynes,' P. Maisonneuve, ${ }^{\star \star}$ H. Bismuth, ${ }^{\ddagger}$ and C. Bréchot ${ }^{\star \star \ddagger}$ \\ ${ }^{*}$ Hybridotest, Institut Pasteur, Paris; ${ }^{\ddagger}$ Unité de chirurgie Hépatobiliaire, ${ }^{\S}$ Banque du Sang, "Bactériologie, 'Anatomo-pathologie, \\ ${ }^{* *}$ Hôpital P. Brousse, Villejuif; Banque du sang, Versailles, ${ }^{\ddagger}$ Unité d'hépatologie \\ and Institut National de la Santé et de la Recherche Medical, U-75 Necker-Laënnec, Paris, France
}

\begin{abstract}
We have investigated hepatitis $\mathrm{C}$ virus (HCV) viremia before and after orthotopic liver transplantation (OLT). 38 patients were examined; 16 were anti-HCV positive and 22 anti-HCV negative pre-OLT in a RIBA-2 test (Ortho Diagnostic Systems Inc., Westwood, MA). HCV-RNA was detected using a modified nested polymerase chain reaction in 14/38 and 10/38 patients before and after OLT, respectively. 7 of these 14 subjects who were HCV-RNA positive before OLT were also positive for serum hepatitis B surface antigen. After OLT, six patients became HCV-RNA positive, likely as a result of transfusions, while four developed a probable recurrence of $\mathrm{HCV}$ infection. Infection of the liver graft by the same strain of HCV was indeed demonstrated by sequence analysis of a hypervariable domain (in the envelope region) in two cases. This establishes the possibility of $\mathrm{HCV}$ recurrence and shows the usefulness of polymerase chain reaction as the only assay currently capable of identifying HCV infection after OLT. (J. Clin. Invest. 1992. 89:1361-1365.) Key words: polymerase chain reaction • RNA • viremia $\bullet$ chronic hepatitis
\end{abstract}

\section{Introduction}

Hepatitis $\mathrm{C}$ virus $(\mathrm{HCV})^{1}$ is a major etiological agent of non- $\mathrm{A}-$ non-B infection (NANB) (1). Hepatitis C virus-related chronic liver diseases are increasingly an indication for orthotopic liver transplantation (OLT). Indeed, HCV tests are positive in $40 \%$ of candidates for OLT in our center (D. Samuel, personal communication).

It has recently been suggested by studies based on serological tests that the liver graft might be infected by HCV (2). However, serological assays are difficult to interpret in the context of immunosuppression. In addition, tests for $\mathrm{HCV}$ antigens are not available and assays only detect antibodies to structural and nonstructural proteins (1). The distinction between recur-

Address reprint requests to: Cyril Féray, M.D., Unite de chirurgie Hepatobiliare, Hopital P. Brousse, Villejuif, France.

Received for publication 10 April 1991 and in revised form 13 December 1991.

1. Abbreviations used in this paper: $\mathrm{HB}_{\mathrm{s}} \mathrm{Ag}$, Hepatitis $\mathrm{B}$ surface antigen; HBV, Hepatitis B Virus; NANB, Non-A, Non-B; NPCR, nested polymerase chain reaction; OLT, orthotopic liver transplantation; PCR, polymerase chain reaction.

J. Clin. Invest.

(c) The American Society for Clinical Investigation, Inc.

$0021-9738 / 92 / 04 / 1361 / 05 \$ 2.00$

Volume 89, April 1992, 1361-1365 rences and acquired $\mathrm{HCV}$ infections due, in particular, to blood transfusions during OLT is therefore a major problem.

We have used the polymerase chain reaction (PCR) procedure (3) to detect HCV RNA (4) in the serum of patients before and after OLT and to compare the corresponding nucleotide sequences in a hypervariable domain of the genome.

\section{Methods}

Patients. 38 patients who underwent liver transplantation between October 1986 and March 1989 at the Villejuif liver transplant center were studied retrospectively. The patients were divided into three groups according to their HCV and HBV serologies at the time of OLT.

Group 1 comprised 16 subjects with a positive test result for anti$\mathrm{HCV}$ antibodies; 7 were also $\mathrm{HBsAg}$-positive. The indications for OLT in this group were $\mathrm{HBsAg}$-positive fulminant hepatitis $(n=2)$, $\mathrm{HBsAg}$ positive cirrhosis $(n=5)$, NANB cirrhosis $(n=8)$, and primary liver cancer $(n=1)$.

Group 2 comprised 12 patients who were anti-HCV-negative and HBsAg-positive. The indications for liver transplantation were cirrhosis $(n=8)$, primary liver cancer $(n=2)$, and fulminant hepatitis $(n=2)$.

Group 3 (controls) comprised 10 anti-HCV and $\mathrm{HBsAg-negative}$ patients with primary biliary cirrhosis $(n=7)$ or primary sclerosing cholangitis $(n=3)$.

Posttransplant immunosuppressive therapy consisted of a combination of prednisone, cyclosporin, and azathioprine. Each patient received blood products from an average of $103(\mathrm{SD}=45)$ different donors. All the HBsAg-positive patients $(n=19)$ were treated with high doses (10,000 IU) of anti-HBs immunoglobulins (HBsIg) during OLT and throughout follow-up to maintain anti-HBs levels above $100 \mathrm{IU} /$ liter (5). Neither the transfusion products nor the liver donors were screened for anti-HCV antibodies at the time of the study.

\section{Procedures}

Serum samples used for serology and PCR were obtained an average of 2 mo before OLT $(\mathrm{SD}=1.7)$ and $12 \mathrm{mo}$ after OLT $(\mathrm{SD}=6.5)$.

\section{Serological tests}

Anti-HCV antibodies. The presence of anti-HCV antibodies was tested for using a recombinant immunoblot assay RIBA-2 (Ortho Diagnostic Systems Inc., Westwood, MA.). This test detects antibodies to epitopes located in capsid (c22) and nonstructural genes (c33, c100.3, and 511).

$\mathrm{HBV}$ markers. Serum $\mathrm{HBsAg}$, anti-HBs, anti- $\mathrm{HBc}$, and $\mathrm{HBeAg}$ titers were measured by means of radioimmunoassay using standard kits (Abbott Diagnostics, South Pasadena, CA). HBV DNA in serum was detected by a spot test assay as previously described (6).

\section{Polymerase chain reaction (PCR) for HCV RNA}

EXTRACTION AND REVERSE TRANSCRIPTION OF HCV RNA $R N A$ extraction. Sera $(120 \mu \mathrm{l})$ were incubated in a lysis buffer consisting of $100 \mathrm{mM}$ Tris- $\mathrm{HCl}(\mathrm{pH} 8), 1 \%$ sodium dodecyl sulfate and $50 \mu \mathrm{g} / \mathrm{ml}$ proteinase $\mathrm{K}$, for $2 \mathrm{~h}$ at $37^{\circ} \mathrm{C}$. RNA was extracted with phenol/chloroform, precipitated with ethanol and lithium chloride $(0.4 \mathrm{M})$, redissolved in $30 \mu \mathrm{l}$ of sterile distilled water, aliquoted and stored at $-80^{\circ} \mathrm{C}$. 
cDNA synthesis. $10 \mu \mathrm{l}$ of RNA solution and $10 \mathrm{pmol}$ of downstream primer were incubated during $5 \mathrm{~min}$ at $65^{\circ} \mathrm{C}$ and rapidly cooled on ice. cDNA synthesis was carried out at $37^{\circ} \mathrm{C}$ for $45 \mathrm{~min}$ after adjustment of the mixture to contain $50 \mathrm{mmol} /$ liter Tris- $\mathrm{HCl} \mathrm{pH} \mathrm{7.5,} 75 \mathrm{mmol} / \mathrm{liter}$ potassium chloride, $6 \mathrm{mmol} /$ liter magnesium chloride, $1 \mathrm{mmol} /$ liter dNTP and 200 IU of MMLV reverse transcriptase (Bethesda Research Laboratories, Gaithersburg, MD), in a final volume of $30 \mu$ l. cDNA was stored at $-20^{\circ} \mathrm{C}$.

\section{NESTED PCR (NPCR)}

NPCR is a highly sensitive two-step procedure in which the products of a first PCR using "outer" primers are reamplified using a second set of "inner" primers located within the previously amplified sequence (4). A major drawback of the conventional nesting strategy is linked to the opening of the reaction tube after the first amplification step, giving a risk of contaminating the second reaction with amplicons (7). To overcome this problem, we have developed a new protocol for NPCR without reopening the reaction tube between the two steps of the procedure.

$5 \mu \mathrm{l}$ of cDNA was first deposited in a 700- $\mu$ l Eppendorf tube, then $45 \mu \mathrm{l}$ of PCR mix (dNTP: $250 \mu \mathrm{M}$ each, KCl: $50 \mathrm{mM}, \mathrm{MgCl} 2: 1.5 \mathrm{mM}$, gelatine: $0.01 \%, 8 \mathrm{pmol}$ of each outer primer (Table I) and $2.5 \mathrm{U}$ of cloned Taq polymerase (Cetus, Emeryville, $\mathrm{CA}$ ) were added. The reaction mixture was then covered with $350 \mu \mathrm{l}$ of mineral oil. The second PCR mix ( $150 \mu$, with $100 \mathrm{pM}$ each inner primer but no Taq polymerase) was injected onto the surface of the mineral oil, forming a droplet within it. The tubes were then subjected to a first amplification ( 25 cycles: $94^{\circ} \mathrm{C}$ for $45 \mathrm{~s}, 45^{\circ} \mathrm{C}$ for $45 \mathrm{~s}$ and $72^{\circ} \mathrm{C}$ for $55 \mathrm{~s}$ ), and then centrifuged for $1 \mathrm{~min}$ in order to mix the second PCR mixture with the first. The second cycle of amplification $\left(94^{\circ} \mathrm{C}\right.$ for $45 \mathrm{~s}, 45^{\circ} \mathrm{C}$ for $45 \mathrm{~s}$ and $72^{\circ} \mathrm{C}$ for $30 \mathrm{~s}$ ) was thus carried out in a final volume of $200 \mu \mathrm{l}$ with an inner/outer primer ratio of 12:1. The products of the first PCR are therefore diluted fourfold. The sensitivity of this procedure is similar to that of conventional nested PCR.

Two different sets of primers were used for each cDNA (Table I). The first set (primers SR1, SR2, SF1, and SF2) is located within the 5' terminal sequence $\left(5^{\prime} \mathrm{NC}\right)$ of the HCV genome (8) which is conserved in all HCV isolates. The second set of primers $(82.0,82.1,82.2$, and 82.3), situated within a hypervariable region of the HCV genome coding for an envelope protein "E2/NS1" (9), was chosen to test the variability of HCV sequences.

ANALYSIS OF PCR PRODUCTS

$20 \mu$ l of each nested PCR product was analyzed by means of electrophoresis on a $1.5 \%$ agarose gel. Bands were visualized by ethidium bromide staining, transferred to nylon membranes (Gene-Screen Plus; New England Nuclear, Boston, MA) (10), and hybridized with ${ }^{32} \mathrm{P}$-labeled probes (Table I).

\section{SPECIFICITY AND SENSITIVITY CONTROLS}

To detect carry-over, we performed HCV-PCR with the following controls: $(a)$ serum-free lysis buffer for the detection of contamination at every step of the procedure, $(b)$ three negative sera (blood donors) for 12 test sera, $(c)$ the PCR mix alone. Measures for the prevention of carry over included drastic separation of pre-PCR and post-PCR steps. It has been shown that most false results with PCR arise during handling of amplification products (11). A standard positive control from an $\mathrm{HCV}$-infected patient with postransfusional hepatitis yielded positive results at dilutions up to $10^{-8}$.

\section{Sequencing of the E2/NS1 region}

PCR products obtained with primers 82.0, 82.1, 82.2 and 82.3 were purified using the low-melting-point agarose procedure (12) and sequenced using T7 DNA polymerase (Pharmacia, Uppsala, Sweden) and primer 82.1.

\section{Histology}

Liver graft biopsies were obtained after OLT at the time of serum collection.

\section{Statistical analysis}

Data were analyzed using Fisher's exact test.

\section{Results}

Before OLT. HCV RNA was detected in 9 of the 16 patients who were anti-HCV-positive (group 1), 5 of the 12 who were anti-HCV-negative (group 2) and none of the controls (group 3).

After OLT. HCV RNA was detected in a total of 10 patients: 3, 4, and 3 in groups 1, 2, and 3, respectively (Table II and Fig. 1). Four patients scored positive for HCV RNA both before and after OLT and six were positive only after OLT (Table II).

The four patients with a positive amplification of the highly conserved sequence (primers $5^{\prime} \mathrm{NC}$ ) both before and after OLT were then tested with primers encompassing the hypervariable domain, located in the $5^{\prime}$ part of E2/NS1 sequence (13). Vari-

Table I. Oligonucleotide Sequences Used for HCV Primers

\begin{tabular}{|c|c|c|c|}
\hline & & $5^{\prime}$ terminal sequence* & $\begin{array}{l}\text { Length of PCR } \\
\text { products }\end{array}$ \\
\hline \multirow{2}{*}{ “Outer" } & $\operatorname{SR} 1\left(\rightarrow^{\ddagger}\right)$ & 5' GCC ATG GGC GTT AGT ATG AG 3'(-259; -239) & 259 \\
\hline & $\operatorname{SR} 1\left(\leftarrow^{\beta}\right)$ & $5^{\prime}$.GG TGC ACG GTC RAC GAG ACC $3^{\prime}(-21 ;-1)$ & bp \\
\hline \multirow[t]{8}{*}{ "Inner" } & $\mathrm{SF} 2(\rightarrow)$ & 5' GTG CAG CCT CCA GGA CCC CCGA $3(-236 ;-216)$ & 212 \\
\hline & $\operatorname{SR2}(\leftarrow)$ & 5' ACG GGT GAG GTA GTA GAC CC 3'(-24; -44) & bp \\
\hline & probe & $5^{\prime}$. CCG GAA TTG CCA GGA CCG GGT CCT TTC TTG $33^{\prime}(-76 ;-46)$ & \\
\hline & \multicolumn{3}{|c|}{ Viral envelope region (ES/NS1) } \\
\hline & $82.0(\rightarrow)$ & 5' CAC TGG GGA GTC CTA GCG GGC 3'(1055-1076) & 482 \\
\hline & $82.3(\leftarrow)$ & 5' GGG CTA GGA GTA AGC AAT A 3'(1537-1518) & bp \\
\hline & $82.1(\rightarrow)$ & 5' TCC ATG GTG GGG AAC TGG GC 3'(1088-1108) & 382 \\
\hline & $82.2(\leftarrow)$ & 5' GGC TTT GGG GGG TAG TCC A 3'(1470-1451) & bp \\
\hline
\end{tabular}

\footnotetext{
* Nucleotide sequences are numbered from initiating codon ATG.

$\pm(\rightarrow)$ sense

$\$(\leftarrow)$ antisense
} 


\begin{tabular}{|c|c|c|c|c|c|c|c|c|c|}
\hline \multirow[b]{2}{*}{ No. Etiology } & \multicolumn{4}{|c|}{ Before OLT } & \multicolumn{5}{|c|}{ After OLT } \\
\hline & $\begin{array}{l}\text { Anti- } \\
\text { HCV } \\
\end{array}$ & $\begin{array}{l}\text { HCV } \\
\text { RNA } \\
\end{array}$ & HBsAG & $\begin{array}{l}\text { HBV } \\
\text { DNA } \\
\end{array}$ & $\begin{array}{l}\text { Anti- } \\
\text { HCV }\end{array}$ & $\begin{array}{l}\text { HCV- } \\
\text { RNA }\end{array}$ & HBsAG & Histology & $\begin{array}{c}\text { Follow } \\
\text { up }(\mathrm{mo})\end{array}$ \\
\hline \multicolumn{10}{|l|}{ Group 1} \\
\hline 1 Fulm. Hep.* & + & - & + & - & + & - & - & Normal & 10 \\
\hline 2 Cirrhosis & + & - & + & - & + & - & - & Normal & 11 \\
\hline 3 Fulm. Hep. & + & - & + & - & + & - & - & Normal & 15 \\
\hline 4 Cirrhosis & + & - & + & + & - & - & + & $\mathrm{CAH}^{\ddagger}$ & 12 \\
\hline 5 Cirrhosis & + & - & + & - & - & - & + & $\mathrm{CAH}$ & 11 \\
\hline 6 Cirrhosis & + & + & + & - & + & + & - & Normal & 6 \\
\hline 7 Cirrhosis & + & + & + & - & + & - & - & Normal & 9 \\
\hline 8 Cirrhosis & + & + & - & - & + & + & - & $\mathrm{CAH}$ & 3 \\
\hline 9 Cirrhosis & + & + & - & - & + & - & - & Rejection & 12 \\
\hline 10 Cirrhosis & + & + & - & - & + & - & - & $\mathrm{CAH}$ & 13 \\
\hline 11 Cirrhosis & + & + & - & - & + & - & - & Rejection & 9 \\
\hline 12 Cirrhosis & + & + & - & - & + & - & - & Normal & 18 \\
\hline 13 Cirrhosis & + & + & - & - & - & + & - & Normal & 14 \\
\hline 14 Cirrhosis & + & + & - & - & - & - & - & Normal & 9 \\
\hline 15 Cirrhosis & + & - & - & - & + & - & - & Normal & 8 \\
\hline 16 PLC $^{\S}$ & + & - & - & - & - & - & - & Normal & 12 \\
\hline \multicolumn{10}{|l|}{ Group 2} \\
\hline 17 Cirrhosis & - & - & + & - & + & + & - & $\mathrm{CAH}$ & 4 \\
\hline 18 Cirrhosis & - & - & + & - & + & + & - & $\mathrm{CAH}$ & 36 \\
\hline 19 Cirrhosis & - & - & + & - & + & + & - & $\mathrm{CAH}$ & 14 \\
\hline 20 Cirrhosis & - & - & + & - & - & - & - & Normal & 13 \\
\hline 21 Cirrhosis & - & - & + & - & - & - & - & Normal & 11 \\
\hline 22 Cirrhosis & - & - & + & - & - & - & - & Cholestasis & 12 \\
\hline 23 Fulm. Hep. & - & - & + & - & - & - & - & Normal & 12 \\
\hline 24 PLC & - & + & + & - & + & - & - & Rejection & 8 \\
\hline 25 Cirrhosis & - & + & + & - & - & + & - & $\mathrm{CAH}$ & 36 \\
\hline 26 Fulm. Hep. & - & + & + & - & - & - & - & Normal & 9 \\
\hline 27 PLC & - & + & + & - & - & - & - & Cholestasis & 10 \\
\hline 28 Cirrhosis & - & + & + & - & - & - & - & Rejection & 12 \\
\hline \multicolumn{10}{|l|}{ Group 3} \\
\hline $29 \mathrm{PBC}^{\| 1}$ & - & - & - & - & + & + & - & $\mathrm{CAH}$ & 11 \\
\hline $30 \mathrm{PBC}$ & - & - & - & - & + & + & - & Normal & 13 \\
\hline $31 \mathrm{PBC}$ & - & - & - & - & + & + & - & Normal & 12 \\
\hline $32 \mathrm{PBC}$ & - & - & - & - & - & - & - & Normal & 15 \\
\hline 33 PBC & - & - & - & - & - & - & - & Normal & 14 \\
\hline $34 \mathrm{PBC}$ & - & - & - & - & - & - & - & Normal & 11 \\
\hline 35 PBC & - & - & - & - & - & - & - & Normal & 9 \\
\hline 36 PSC $^{1}$ & - & - & - & - & - & - & - & Normal & 14 \\
\hline 37 PSC & - & - & - & - & - & - & - & Normal & 15 \\
\hline 38 PSC & - & - & - & - & - & - & - & Normal & 12 \\
\hline
\end{tabular}

* Fulminant hepatitis. $\quad{ }^{\ddagger}$ Chronic active hepatitis. $\quad$ "Primary liver cancer. "Primary biliary cirrhosis " Primary sclerosing cholangitis.

able sequences could be amplified both pre- and post-OLT in two patients $(8,13)$. Fig. 2 and Table III show the results obtained in these two cases and in a patient (No. 29) with acquired, probably posttransfusional hepatitis. In both cases preand post-OLT nucleotide sequences were highly conserved $(95$ and $96 \%$ ). In addition, the degree of homology was higher between paired pre- and post-OLT isolates than when the five isolates were compared each other or with published American (14) and Japanese isolates (15) (Fig. 2). These results demonstrated that the liver graft was indeed infected by the pre-OLT strain in both cases.
Table II compares the results of the anti-HCV and HCV RNA assays. Two of the 20 patients who were anti-HCV negative after OLT, scored positive for HCV RNA. Conversely, 10 of the 18 subjects who were anti-HCV positive after OLT were HCV RNA-negative.

Liver histology was available for all patients. Chronic Hepatitis was significantly more frequent in patients with positive $\mathrm{HCV}$ viremia $(6 / 10$ vs $2 / 28 ; P<0.01)$. It is noteworthy that none of the 6 patients with HCV viremia and chronic hepatitis had evidence of associated HBV infection. Among the 28 HCV-RNA negative patients, 2 showed HBV-related chronic 


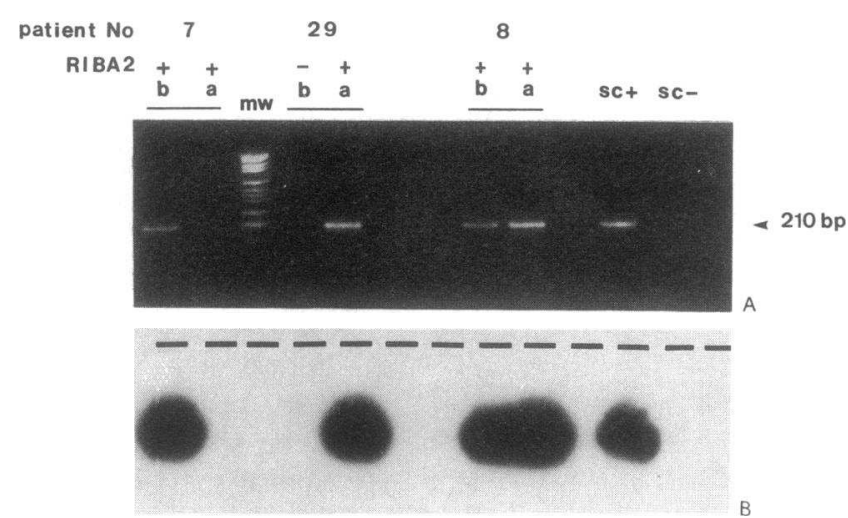

Figure 1. Detection of HCV RNA by nested PCR (primers 5 ' NC). Patients 7, 29, and 8 before $(b)$ and after $(a)$ OLT. SC+, positive standard control. SC-, negative control. $(A)$ Ethidium bromide staining. $(B)$ Hybridization with ${ }^{32} \mathrm{P}$-labeled oligonucleotide probe (30 min exposure).

hepatitis. These 2 subjects were the only subjects among the 19 $\mathrm{HBs} A g$ positive individuals who showed evidence for $\mathrm{HBV}$ recurrence as assessed by positive serum HBs Ag and HBV DNA assays. This low rate of recurrence is explained by a low prevalence of HBV replication before OLT (1/19) together with long-term immunoprophylaxis with $\mathrm{HBsIg}$ (16).

\begin{tabular}{|c|c|c|c|c|c|c|c|c|}
\hline $\begin{array}{ll}1 & \text { GGGGGA } \\
2 & \ldots\end{array}$ & $\begin{array}{l}\text { AGT } \\
\ldots\end{array}$ & $\begin{array}{l}\text { GCC } \\
\ldots \\
\end{array}$ & $\begin{array}{l}\text { GCC } \\
. \text { G. }\end{array}$ & $\begin{array}{l}\mathrm{CAC} \\
\ldots\end{array}$ & $\begin{array}{l}\mathrm{ACT} \\
\ldots\end{array}$ & $\begin{array}{l}\mathrm{ACC} \\
\ldots \\
\end{array}$ & $\begin{array}{l}\text { GGT } \\
\ldots \text { C }\end{array}$ & $\begin{array}{l}\text { TGA } \\
\ldots \mathrm{T} \\
\end{array}$ \\
\hline $\begin{array}{l}1 \\
1 \\
2\end{array} \ldots \ldots$ & 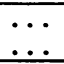 & $\begin{array}{l}. \mathrm{TT} \\
\ldots \mathrm{T}\end{array}$ & $\begin{array}{l}\text { CGT } \\
\text { CGT }\end{array}$ & $\begin{array}{l}\text { TCG } \\
\text { TCT }\end{array}$ & $\begin{array}{l}\ldots \mathrm{C} \\
\ldots \mathrm{C} \\
\end{array}$ & $\begin{array}{l}\ldots G \\
\ldots G \\
\end{array}$ & $\begin{array}{l}\mathrm{CA} \text {. } \\
\mathrm{CA} \text {. }\end{array}$ & $\begin{array}{l}\text { G.. } \\
\text { G.. }\end{array}$ \\
\hline $\begin{array}{l}3 \ldots \\
4 \ldots \\
5\end{array} \ldots$ & $\begin{array}{l}\cdots \\
\ddot{G T G}\end{array}$ & $\begin{array}{l}\cdots \\
\ddot{C A A}\end{array}$ & $\begin{array}{l}. .9 \\
. G .\end{array}$ & $\begin{array}{l}\mathrm{ACA} \\
\cdots \\
\cdots\end{array}$ & $\begin{array}{l}\cdots \\
\ddot{G T C}\end{array}$ & $\begin{array}{c}\ldots \mathrm{G} \\
\mathrm{GTG} \\
\ldots\end{array}$ & $\begin{array}{l}\ldots \mathrm{C} \\
\mathrm{TC} . \\
\mathrm{TC} .\end{array}$ & $\begin{array}{l}\dot{. C} \text { C } \\
\text { G. } \\
\text { AC. }\end{array}$ \\
\hline 1994 & & & & & & & & \\
\hline 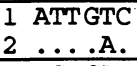 & $\begin{array}{l}\text { TAG } \\
\ldots \\
\end{array}$ & $\begin{array}{l}\text { TAT } \\
\ldots \\
\end{array}$ & $\begin{array}{l}\text { TTA } \\
\ldots \mathrm{C} \\
\end{array}$ & $\begin{array}{l}\mathrm{ACA} \\
\ldots \\
\end{array}$ & $\begin{array}{l}\mathrm{CCA} \\
\ldots \\
\end{array}$ & $\begin{array}{c}\text { GGC } \\
\ldots\end{array}$ & $\begin{array}{l}\text { GCC } \\
\ldots \\
\end{array}$ & $\begin{array}{c}\text { AAG } \\
\ldots\end{array}$ \\
\hline $\begin{array}{l}1^{\prime} \cdot \mathrm{C} \cdot \mathrm{CA} \text {. } \\
2^{\prime} \cdot \mathrm{C} \cdot \mathrm{CA} .\end{array}$ & $\begin{array}{l}\text { C... } \\
\text { C.. }\end{array}$ & $\begin{array}{l}. \mathrm{T} . \\
. \mathrm{T} . \\
\end{array}$ & $\begin{array}{l}\ldots \mathrm{T} \\
\ldots \\
\end{array}$ & $\begin{array}{l}\text { CTC } \\
\text { CTC }\end{array}$ & $\begin{array}{l}\text { T... } \\
\text { T.. }\end{array}$ & $\begin{array}{l}\ldots \mathrm{G} \\
\ldots \mathrm{G} \\
\end{array}$ & $\begin{array}{l}\cdots \\
\cdots \\
\end{array}$ & $\begin{array}{l}. \mathrm{G} . \\
. \mathrm{G} .\end{array}$ \\
\hline $\begin{array}{ll}3 & \text { CACTA. } \\
4 & \text { T. . . T } \\
5 & \text { C. СACG }\end{array}$ & $\begin{array}{l}\ddot{A G C} \\
. C C\end{array}$ & $\begin{array}{l}\ldots \ldots \\
\text { CTC } \\
\text { CTC }\end{array}$ & $\begin{array}{l}. \cdot \mathrm{G} \\
\mathrm{C} \cdot \mathrm{C} \\
\ldots \mathrm{T}\end{array}$ & $\begin{array}{l}\text { TTG } \\
\text { G.. } \\
. \text { G. }\end{array}$ & $\begin{array}{l}\text { G. } \\
\ldots \\
\ldots \mathrm{T}\end{array}$ & $\begin{array}{c}\text { ACG } \\
\ldots \\
\ldots G\end{array}$ & $\begin{array}{l}\cdots \\
\cdots \\
\cdots G\end{array}$ & $\begin{array}{l}\cdots \\
\cdots \\
\text { TTC }\end{array}$ \\
\hline 2224 & & & & & & & & \\
\hline $\begin{array}{ll}1 & \text { CAGAAC } \\
2 & \ldots \ldots\end{array}$ & $\begin{array}{l}\text { ATC } \\
\ldots . \\
\end{array}$ & $\begin{array}{l}\mathrm{CAG} \\
\ldots\end{array}$ & $\begin{array}{l}\text { CTG } \\
\ldots\end{array}$ & $\begin{array}{l}\text { ATC } \\
\ldots \\
\end{array}$ & $\begin{array}{l}\text { AAC } \\
\ldots \\
\end{array}$ & $\begin{array}{l}\mathrm{ACC} \\
\ldots \\
\end{array}$ & $\begin{array}{l}\text { AAT } \\
\ldots \\
\end{array}$ & $\begin{array}{l}\text { GGC } \\
\ldots \\
\end{array}$ \\
\hline 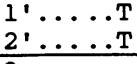 & $\begin{array}{l}\cdots \\
\cdots \\
\end{array}$ & $\ddot{m}$ & $\begin{array}{l}\text { TGT } \\
\text { TGT }\end{array}$ & $\begin{array}{l}. \text { A. } \\
. \mathrm{A}\end{array}$ & $\begin{array}{l}. \mathrm{T} . \\
. \mathrm{T} .\end{array}$ & $\begin{array}{l}. A . \\
. A .\end{array}$ & $\begin{array}{l}. \mathrm{T} \\
. \mathrm{T} \\
\end{array}$ & 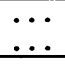 \\
\hline $\begin{array}{l}3 \ldots \\
4 \\
5\end{array} \ldots \ldots$ & $\begin{array}{l}\ldots \\
\mathrm{G} . \dot{T} \\
\ldots\end{array}$ & $\begin{array}{l}\cdots \\
\cdots \\
\cdots\end{array}$ & $\begin{array}{l}. \mathrm{CT} \\
\cdots \\
\cdots \mathrm{T}\end{array}$ & $\begin{array}{l}\ldots G \\
\ddot{G} \cdot \dot{A}\end{array}$ & $\begin{array}{l}\cdots \\
\cdots \\
\cdots\end{array}$ & $\begin{array}{l}\cdots \\
\cdots \\
\cdots\end{array}$ & $\begin{array}{l}\ldots C \\
\cdots C \\
\cdots\end{array}$ & $\begin{array}{l}\cdots \\
\cdots \\
\cdots\end{array}$ \\
\hline 2254 & & & & & & & & \\
\hline $\begin{array}{lll}1 & \text { AGT TGG } \\
2 & \ldots & \ldots \\
\end{array}$ & $\begin{array}{l}\mathrm{CAC} \\
\ldots \\
\end{array}$ & $\begin{array}{l}\text { ATC } \\
\ldots \ldots \\
\end{array}$ & $\begin{array}{l}\mathrm{AAT} \\
\ldots \\
\end{array}$ & $\begin{array}{l}\text { AGG } \\
\ldots \\
\end{array}$ & $\begin{array}{l}\text { ACG } \\
\ldots \\
\end{array}$ & & & \\
\hline $\begin{array}{l}1 \\
2\end{array} \ldots \ldots$ & $\cdots$ & & $\begin{array}{l}\ldots C \\
\ldots C \\
\end{array}$ & $\begin{array}{l}\cdots \\
\cdots \\
\end{array}$ & $\cdots$ & & & \\
\hline $\begin{array}{l}3 \ldots \\
4 \\
4\end{array} \ldots$ & $\begin{array}{l}\ldots G \\
\ldots T\end{array}$ & $\begin{array}{l}\cdots \\
\cdots T \\
\cdots\end{array}$ & $\begin{array}{l}\cdots \\
\cdots \\
\cdots C\end{array}$ & $\begin{array}{l}\cdots \\
\cdots C \\
\cdots\end{array}$ & $\begin{array}{l}\ldots \mathrm{T} \\
\cdots \mathrm{T}\end{array}$ & & & \\
\hline
\end{tabular}

Figure 2. Nucleotide sequence of the hypervariable domain of 5' part of E2/NS1 of HCV RNA before and after OLT. Nucleotide sequences of the hypervariable domain of the E2/NS1 region before (lane 1; lane $1^{\prime}$ ) and after (lane 2; lane $2^{\prime}$ ) OLT in patients 8 and 13, respectively. Nucleotide sequence of the same region of E2/NS1 in patient 29 with acquired, posttransfusional hepatitis (lane 3 ) and from two published reports. HCVpt (lane 4) and HCVJ1 (lane 5) isolates (European patent application 90302866.0; Takeuchi et al., 1990). The numbering corresponds to $\mathrm{HCVpt}$ (European patent application 90302866.0). Dots indicate identical sequences.
Table III. Nucleotide Sequence Homologies (\%) in the Hypervariable Domain of the 5' Part of E2/NS1

\begin{tabular}{|c|c|c|c|c|c|c|c|c|}
\hline HCV J1 (5) & & 5 & 63 & 66 & 55 & 52 & 55 & 63 \\
\hline HCV-Pt (4) & & 4 & 78 & 77 & 64 & 63 & 65 & - \\
\hline No. 29 & After OLT & 3 & 76 & 78 & 65 & 65 & - & \\
\hline \multirow[t]{2}{*}{ No. 13} & After OLT & $2^{\prime}$ & 70 & 67 & 96 & - & & \\
\hline & Before OLT & $1^{\prime}$ & 68 & 69 & - & & & \\
\hline \multirow[t]{3}{*}{ No. 8} & After OLT & 2 & 95 & - & & & & \\
\hline & Before OLT & 1 & - & & & & & \\
\hline & & & 1 & 2 & $1^{\prime}$ & $2^{\prime}$ & 3 & 4 \\
\hline
\end{tabular}

Sequences of HCV RNA from 3 patients in the present study are shown, including 2 with HCV recurrence (patients 8 and 13 in Table II) and 1 with posttransfusional hepatitis (patient 29 in Table II). Lanes 1 and 2 correspond to pre-OLT and post-OLT HCV RNA sequences in patient 8 , while lanes $l^{\prime}$ and $2^{\prime}$ correspond to those of patient 13. Lane 3 indicates the sequence of HCV RNA in patient 29. Other sequences from the literature are included for additional comparison: HCVpt (4) and HCVJ1 (5) isolates (European patent application 90302866.0; Takeuchi et al., 1990). The numbering corresponds to HCVpt (European patent application 90302866.0).

\section{Discussion}

Our findings provide direct evidence that $\mathrm{HCV}$ infection can recur in liver transplant recipients. Indeed, of the ten subjects who were HCV-RNA positive after OLT, four were also positive before the transplantation. We documented the recurrence of HCV infection in two patients by the comparative study of a hypervariable domain of the HCV genome before and after OLT. The nucleotide homology was indeed very high, relative to that of distinct isolates. The infection of the engrafted liver by the initial HCV strain probably involved circulating virions. However, it could also occur via infected nonliver cells, as previously suggested for $\operatorname{HBV}(17,18)$. Preliminary results indeed suggest that peripheral blood mononuclear cells can be infected by HCV (19, and Zignego, A. L., manuscript submitted for publication).

The actual prevalence of $\mathrm{HCV}$ recurrence in OLT patients cannot be derived from our data. Although the rate was low, it should indeed be borne in mind that we only analyzed a single sample obtained from each patients at a mean of 12 mo after OLT. Additional intermittent, transient or late $\mathrm{HCV}$ infections cannot thus be excluded.

It is also interesting to note that some of these patients bore markers of both HCV and HBV infection before OLT. It is tempting to speculate that such coinfection might attenuate $\mathrm{HCV}$ viremia before OLT and, thus, the risk of $\mathrm{HCV}$ reinfection. In addition anti-HBs antibody preparations, used to prevent $\mathrm{HBV}$ recurrences in these subjects, might contain anti$\mathrm{HCV}$ antibodies although the batches we have tested have been negative in a RIBA-II assay. 6 of the 38 subjects had acquired $\mathrm{HCV}$ infection after OLT. It is noteworthy that this study was undertaken before the exclusion of anti-HCV positive blood and liver donors became possible. Although screening of blood products with serological tests is quite efficient (20), the number of donors necessary to transfuse organ recipients is large, and the frequency of transfusion-related infection might well remain high. 
Interestingly, HCV viremia was only associated with chronic hepatitis in patients who showed no evidence of associated HBV infection. With regard to the development of hepatic lesions, the respective role of a direct cytopathic effect of $\mathrm{HCV}$ and the host immune response to viral and cellular antigens is not known. However, severe chronic active hepatitis has been reported in patients infected with both HCV and HIV (21). Taken together our results indicate that HCV may be a significant cause of liver disease following OLT.

Finally, although anti-HCV antibodies were sought using the RIBA-2 test, $2 / 20$ of the patients who were anti-HCV negative after OLT were HCV RNA-positive. Thus serological status after OLT was not able to distinguish recurrent from acquired, posttransfusional HCV infection. Therefore, detection by PCR of HCV RNA is currently the only method for appraising HCV infection following liver transplantation.

\section{Acknowledgments}

The authors thank D. Castaing, J. P. Benhamou, J. Bernuau, and F. Saliba, for including patients in the liver transplant program. C. Féray holds grants from the Fondation pour la Recherche Médicale and the Fondation Maurice Rapin. This work was supported by Institut National de la Santé et de la Recherche Médicale U75, CNAM, ARC (6252), LNC and Pasteur-Diagnostic.

\section{References}

1. Choo, Q. L., G. Kuo, A. J. Weiner, L. R. Overby, D. W. Bradley, and M. Houghton. 1989. Isolation of a cDNA clone derived from blood borne non-A non-B viral hepatitis genome. Science (Wash. DC). 244:359-362.

2. Martin, P., S. J. Munoz, A. M. Di Bisceglie, R. Rubin, J. G. Waggoner, V. T. Armenti, M. J. Moritz, B. E. Jarell, and W. C. Maddrey. 1991. Recurrence of hepatitis $\mathrm{C}$ virus infection after orthotopic liver transplantation. Hepatology. 13:719-721.

3. Saiki, R. K., S. Scarf, F. Faloona, K. B. Mullis, G. T. Horn, H. A. Erlich, and N. Arnheim. 1985. Enzymatic amplification of beta globin genomic sequences and restriction analysis for diagnosis of sickle cell anaemia. Science (Wash. DC). 230:1350-1354.

4. Garson, J. A., P. W. Tuke, M. Makris, M. Briggs, J. S. Machin, F. E Preston, and R. S. Tedder. 1990. Demonstration of viræmia patterns in haemophiliacs treated with hepatitis-C-virus-contaminated factor VIII concentrates. Lancet 336:1022-1025.

5. Lauchart, W., R. L. Muller, and R. Pichlmayr. 1987. Long-term immuno- prophylaxis of hepatitis B virus reinfection in recipients of human liver allografts. Transplant. Proc. 19:4051.

6. Scotto, J., M. Hadchouel, C. Hery, J. Yvert, P. Tiollais, and C. Bréchot. 1983. Detection of hepatitis B virus. DNA in serum by a simple spot hybrization technique: comparison with results for other viral markers. Hepatology. 3:279287.

7. Erlich, H. A., D. Gelfand, and J. J. Sninsky. 1991. Recent advances in the polymerase chain reaction. Science (Wash. DC). 252:1643-1651.

8. Okamoto, H., S. Okada, M. Sugiyama, T. Yotsumoto, H. Tanaka, F. Yoshizawa, F. Tsuda, Y. Mikayawa, and M. Mayumi. 1990. The $5^{\prime}$ terminal sequence of hepatitis C virus genome. Jpn. J. Exp. Med. 60:167-177.

9. Weiner, A. J., M. J. Brauer, J. Rosenblatt, K. H. Richman, J. Tung, K. Crawford, F. Bonino, G. Saracco, Q. L. Choo, M. Houghton, and J. H. Han. 1991. Variable and hypervariable domains are found in the region of HCV corresponding to the flavivirus envelope and NS1 proteins and the pestivirus envelope glycoproteins. Virology. 180:842-848.

10. Thiers, V., E. Nakajima, D. Kremsdorf, D. Mack, H. Schellekens, F. Driss, A. Goudeau, J. Wands, J. Sninsky, P. Tiollais, and C. Bréchot. 1988. Transmission of hepatitis B from hepatitis-B-seronegative subject. Lancet. ii:1273-1276.

11. Kwok, S., and R. Higushi. 1989. Avoiding false positives with PCR. Nature (Lond.). 339:237-38.

12. Sambrook, J., E. Fritsh, and T. Maniatis. 1989. Molecular Cloning. A Laboratory Manual. Cold Spring Harbor Laboratory Press, Cold Spring Harbor, New York.

13. Houghton, M., A. Weiner, J. Hang, G. Kuo, and Q. L. Choo. 1991. Molecular biology of the hepatitis $\mathrm{C}$ viruses: implications for diagnosis, development and control of viral disease. Hepatology. 14:381-388.

14. Choo, Q. L., K. H. Richman, J. H. Han, K. Berger, C. Lee, C. Dong, and C. Gallegos. 1991. Genetic organization and diversity of the hepatitis $\mathrm{C}$ virus. Proc. Natl. Acad. Sci. USA. 88:2451-2455.

15. Takeuchi, K., Y. Kubo, S. Boonmar, Y. Watanabe, T. Katayama, Q. L Choo, G. Kuo, M. Houghton, I. Saito, and T. Miyamura. 1990. Nucleotide sequence of côre and envelope genes of the hepatitis $\mathrm{C}$ virus genome derived directly from human healthy carriers. Nucleic Acid Res. 18:4626.

16. Samuel, D., A. Bismuth, D. Mathieu, J. L. Arulnaden, M. Reynes, J. P. Benhamou, C. Brechot, and H. Bismuth. 1991. Passive immunoprophylaxis after liver transplantation in HBsAg-positive patients. Lancet. 337:813-815r.

17. Zignego, A. L., D. Samuel, J. Gugenheim, J. Chardan, A. Bismuth, M. Hadchouël, M. Reynes, C. Brechot, and H. Bismuth. 1988. Hepatitis B virus replication and mononuclear blood cell infection. In Viral Hepatitis and Liver Diseases. A. J. Zuckerman, editor. Alan R. Liss, New York. 808-809.

18. Féray, C., A. L. Zignego, D. Samuel, A. Bismuth, M. Reynes, P. Tiollais, H. Bismuth, and C. Bréchot. 1990. Persistent hepatitis B virus infection of mononuclear blood cells without concomitant liver infection. Transplantation. 49:1155-1158.

19. Weiner, J. and J. Steimer, S. 1990. European patent. \#903091 205

20. Esteban, J. I., A. Gonzalez, J. M. Hernandez, L. Viladomiu, C. Sanchez, J. C. Lopez-Tavarela, and D. Lucea. 1990. Evaluation of antibodies to hepatitis C virus in a study of transfusion-associated hepatitis. N. Engl. J. Med. 323:11071112.

21. Martin, P., A. M. Di Bisceglie, C. Kassiandes, M. Lisker-Melmav, and J. Hoofnagle. 1989. Rapidly progressive non A-non B hepatitis in patients with human immunodeficiency virus infection. Gastroenterology. 97:1559-1561. 